\title{
Genotyping single nucleotide polymorphisms for allele-selective therapy in Huntington disease
}

Daniel O. Claassen, MD, Jody Corey-Bloom, MD, PhD, E. Ray Dorsey, MD, Mary Edmondson, MD, Sandra K. Kostyk, MD, PhD, Mark S. LeDoux, MD, PhD, Ralf Reilmann, MD, H. Diana Rosas, MD, Francis Walker, MD, Vicki Wheelock, MD, Nenad Svrzikapa, MS, Kenneth A. Longo, PhD, Jaya Goyal, PhD, Serena Hung, MD, and Michael A. Panzara, MD, MPH

Neurol Genet 2020;6:e430. doi:10.1212/NXG.0000000000000430

\section{Abstract}

\section{Background}

The huntingtin gene (HTT) pathogenic cytosine-adenine-guanine (CAG) repeat expansion responsible for Huntington disease (HD) is phased with single nucleotide polymorphisms (SNPs), providing targets for allele-selective treatments.

\section{Objective}

This prospective observational study defined the frequency at which rs362307 (SNP1) or rs362331 (SNP2) was found on the same allele with pathogenic CAG expansions.

\section{Methods}

Across 7 US sites, 202 individuals with HD provided blood samples that were processed centrally to determine the number and size of CAG repeats, presence and heterozygosity of SNPs, and whether SNPs were present on the mutant HTT allele using long-read sequencing and phasing.

\section{Results}

Heterozygosity of SNP1 and/or SNP2 was identified in 146 (72\%) individuals. The 2 polymorphisms were associated only with the $\mathrm{mHTT}$ allele in $61 \%$ (95\% high density interval: $55 \%$, $67 \%)$ of individuals.

\section{Conclusions}

These results are consistent with previous reports and demonstrate the feasibility of genotyping, phasing, and targeting of HTT SNPs for personalized treatment of HD.
Correspondence

Dr. Claassen

Daniel.Claassen@vumc.org

From the Vanderbilt University Medical Center (D.O.C.), Nashville, TN; University of California San Diego (J.C.-B.), La Jolla; University of Rochester Medical Center (E.R.D.), NY; HD Reach (M.E.), Raleigh, NC; Ohio State University (S.K.K.), Columbus; University of Memphis and Veracity Neuroscience, LLC (M.S.L.), TN; George-Huntingon-Institute \& Department of Clinical Radiology University of Muenster (R.R.), Department of Neurodegeneration, Hertie Institute for Clinical Brain Research, University of Tuebingen, Germany; Havard Medical School (H.D.R.), Massachusetts General Hospital, Boston; Wake Forest University School of Medicine (F.W.), Winston Salem, NC; University of California Davis Health (V.W.), Sacramento, CA; Wave Life Sciences USA, Inc. (N.S., K.A.L., J.G., S.H., M.A.P.), Cambridge, MA; and Department of Paediatrics (N.S.), Medical Sciences Division, University of Oxford, UK. 


\section{Glossary}

$\mathbf{C A G}=$ cytosine-adenine-guanine $\mathbf{H D}=$ Huntington disease $; \mathbf{m H T T}=$ mutant $H T T ; \mathbf{S N P}=$ single nucleotide polymorphism; $\mathbf{w t H T T}=$ wild-type HTT; UHDRS = Unified Huntington Disease Rating Scale.

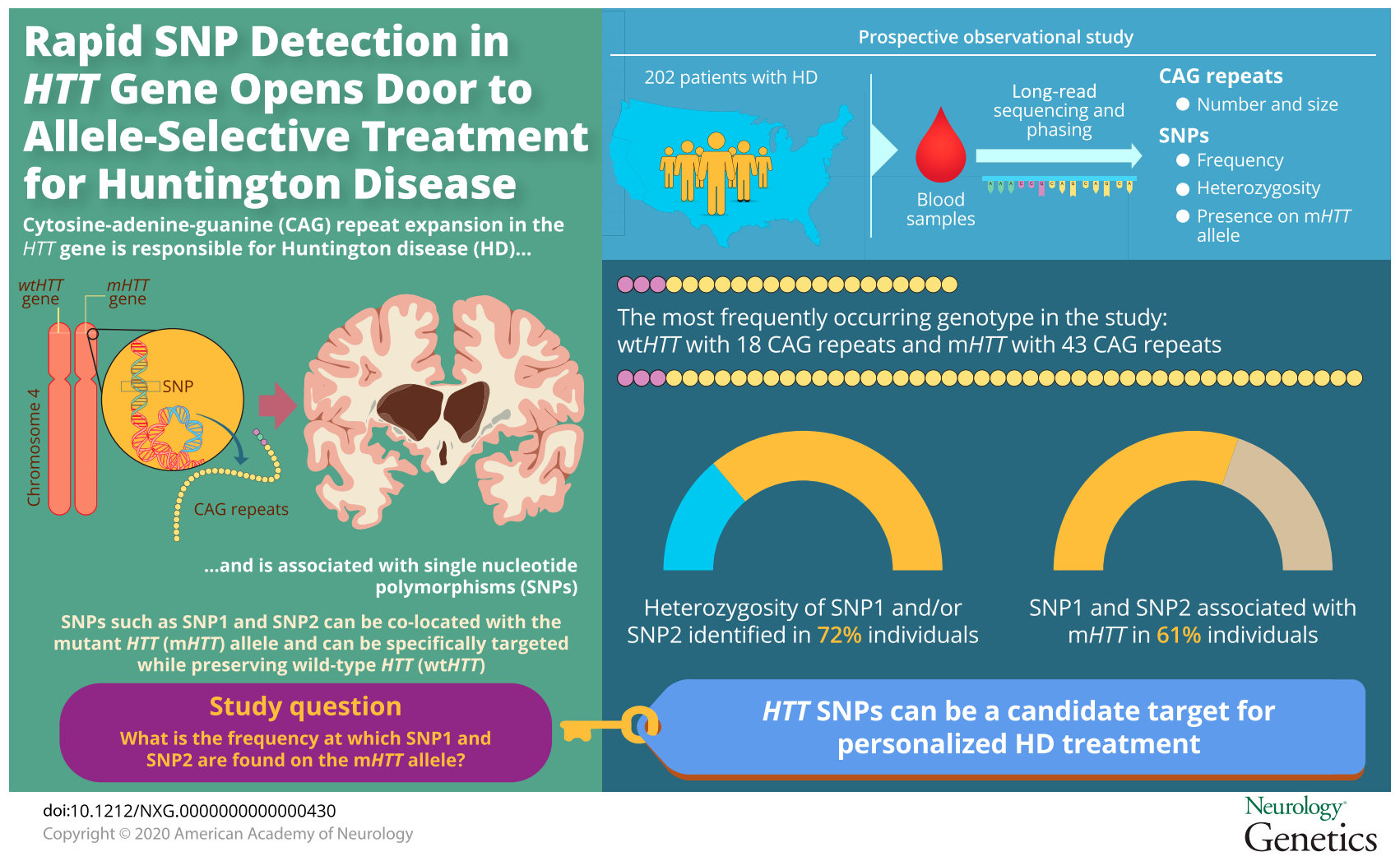

Most individuals with Huntington disease (HD) are heterozygous for the cytosine-adenine-guanine (CAG) repeat, having one wild-type (wtHTT) and one abnormally expanded mutant huntingtin gene $(m H T T)$ allele. ${ }^{1}$ Allele-selective targeting of the mHTT transcript offers a personalized approach to HD treatment $^{1}$ and has the potential advantage of keeping wtHTT protein relatively intact. It has been suggested that wtHTT protein is required for normal neurologic function and may be neuroprotective in the adult brain. ${ }^{2-4}$ One approach is to target specific single nucleotide polymorphisms (SNPs) found on the $m H T T$ allele. Multiple SNPs have an increased frequency in $\mathrm{HD}$ but do not affect diagnosis or disease course. ${ }^{5,6}$ According to previous reports, $65 \%-70 \%$ of individuals with $\mathrm{HD}$ of European ancestry carry SNP rs362307 (SNP1), SNP rs362331 (SNP2), or both SNPs. ${ }^{1}$ According to the Genome Aggregation Database (gnomAD.broadinstitute.org), SNP1 and SNP2 frequencies vary by population and are higher in Latinos and Africans, respectively, whereas both are lower in Asian populations. For selective treatment to be feasible, an individual must be heterozygous for a target SNP and it must be colocated on the same allele or haplotype phased, with the expanded CAG repeat. In this observational study, individuals with $\mathrm{HD}$ were recruited from HD clinics in the United States (US), genotyped, and experimentally phased to evaluate the prevalence of SNP1 and SNP2 on the same allele as the expanded CAG repeat.

\section{Methods}

Ambulatory men and women aged 25-65 years with diagnostic motor features of $\mathrm{HD}$ (Unified Huntington Disease Rating Scale $[\text { UHDRS }]^{7}$ Diagnostic Confidence Score of 4 and stage I or II HD with UHDRS Total Functional Capacity scores $\geq 7$ ) were eligible. At one clinic visit, blood samples were collected in PAXgene Blood DNA and RNA tubes (PreAnalytiX, Switzerland) as per manufacturer's instructions and shipped frozen for processing.

Blood samples were processed at a central laboratory using 3 steps. First, the number of CAG repeats was confirmed by PCR and the size was determined using a Bioanalyzer (3500 Genetic Analyzer, Applied Biosystems, San Francisco, CA). Second, zygosity at the targeted SNP(s) was determined by Sanger sequencing. Finally, for samples with confirmed normal and expanded CAG repeats and SNP heterozygosity at either SNP1 or SNP2, a PacBio (Menlo Park, CA) long-read sequencing investigational assay determined the haplotype phase of the SNP with the CAG expansion.

Demographic information was descriptively summarized. The frequency of SNP1 or SNP2 T variant on $m H T T$ was determined as the posterior chain product probability of 
the frequency of heterozygosity at either SNP and the frequency of the $\mathrm{U}$ variant on the $m H T T$ allele. The probability was calculated using a beta distribution model, which provides the mode and 95\% highest density intervals. SNP prevalence was compared across sites and by sex and ethnicity.

\section{Standard protocol approvals and data availability}

This observational study was conducted in accordance with the Declaration of Helsinki with ethics committees' approval from all 7 participating US centers. Anonymized data will be shared on request from any qualified investigator.

\section{Results}

\section{Participants}

From February 2017 to September 2018, 203 individuals with HD were enrolled (table); 1 individual was excluded for older age.

\section{SNP heterozygosity and phasing}

Nearly three-quarters of individuals $(146 / 202 ; 72 \%)$ were heterozygous for SNP1 only $(\mathrm{n}=52)$, SNP2 only $(\mathrm{n}=46)$, or both SNPs $(\mathrm{n}=48)$ (figure 1$)$. Thus, approximately one-quarter of individuals $(56 / 202 ; 28 \%)$ were found to have the same SNP on both alleles or did not have a SNP on either allele. Among the heterozygotes, the sequencing results to determine SNP haplotype phasing

Table Characteristics of study participants

\begin{tabular}{ll}
\hline Characteristics & $\begin{array}{l}\text { Individuals with } \\
\text { HD ( } \mathbf{N}=\mathbf{2 0 3})\end{array}$ \\
\hline Age, $\mathbf{y}$, mean (SD) & $49.7(10.0)$ \\
\hline Sex, $\mathbf{n}(\%)$ & $104(51)$ \\
\hline Male & $99(49)$ \\
\hline Female & \\
\hline Race, $\mathbf{n}(\%)$ & $193(95)$ \\
\hline White & $6(3)$ \\
\hline Black or African American & $2(1)$ \\
\hline Native American or Alaska Native and White & \\
\hline Asian & $1(0.5)$ \\
\hline Native Hawaiian or other Pacific Islander & $1(0.5)$ \\
\hline Ethnicity, $\mathbf{n}$ (\%) & $12(6)$ \\
\hline Hispanic or Latino & $191(94)$ \\
\hline Not Hispanic or Latino & $43(38-62)$ \\
\hline CAG repeats, median (range) & \\
\hline
\end{tabular}

Abbreviations: $C A G$ = cytosine-adenine-guanine; $\mathrm{HD}=$ Huntington disease. a Two participants indicated American Indian and White. with CAG expansion were available for 128 individuals, of which $108(84 \%)$ had SNP1 only $(\mathrm{n}=41)$, SNP2 only $(\mathrm{n}=28)$, or both SNPs $(\mathrm{n}=39)$ present on the mHTT allele (figure 1). For the other 20 heterozygous individuals, target SNPs were found on the wtHTT allele. Two individuals had expanded CAG repeats on both alleles. Sixteen individuals had inconclusive phasing results because of failed quality control on multiple sample processing attempts (up to 4 ) and interpretable data could not be provided.

The most frequently occurring genotype for HTT was a normal allele with 18 CAG repeats and mutant allele with 43 CAG repeats (figure 2). The prevalence of SNP1 and/or SNP2 was consistent across study sites and independent of the sex of individuals. Because of the small numbers of individuals with different ethnicities, no conclusions regarding ethnicity and SNP prevalence could be made.

Overall, the frequency at which SNP1 and/or SNP2 were associated only with the $\mathrm{mHTT}$ allele in this observational cohort was 0.61 (95\% high-density interval: $0.55,0.67$ ), based on the probability of both SNP heterozygosity and phasing on the $\mathrm{mHTT}$ allele $([146 / 202] \times[108 / 128])$.

\section{Discussion}

This is the first study to demonstrate the feasibility of rapid assessment of SNP prevalence and haplotype phasing in a relatively large number of individuals with $\mathrm{HD}(>200)$ using nextgeneration sequencing of $\mathrm{HD}$ transcript. Heterozygosity for SNP1, SNP2, or both SNPs was established in most individuals with HD (61\%). These results suggest that clinical trials in this population are feasible and future SNP1/2 selective treatments could potentially address a significant portion of the HD population.

This study directly phased patient samples, and the results are consistent with SNP frequencies reported in previous studies using computational methods. ${ }^{5,8,9}$ Pfister et al. ${ }^{5}$ sequenced 24 SNPs using genomic DNA from 109 German and US individuals with HD and found an increased frequency of SNP1 (>48\%) vs other SNPs. The addition of 2 SNP sites was calculated to incorporate approximately $75 \%$ of the individuals with HD tested. ${ }^{5}$ In another study, unrelated Italian (European Caucasian) individuals with HD heterozygous for the CAG repeat $(\mathrm{N}=327)$ were genotyped at 26 SNP sites, including SNP1 and SNP2. ${ }^{8}$ Of these, $86 \%$ of individuals were heterozygous at one or more SNP loci and may be amenable to allele-selective therapy. SNP2 heterozygosity was most prevalent in this HD population $(46.2 \%)$, increasing the estimated probability of heterozygosity at either SNP1 or SNP2 to $65 \% .{ }^{8}$ Using the University of British Columbia and Tissue Bank for HD Research database, direct sequencing was performed for 


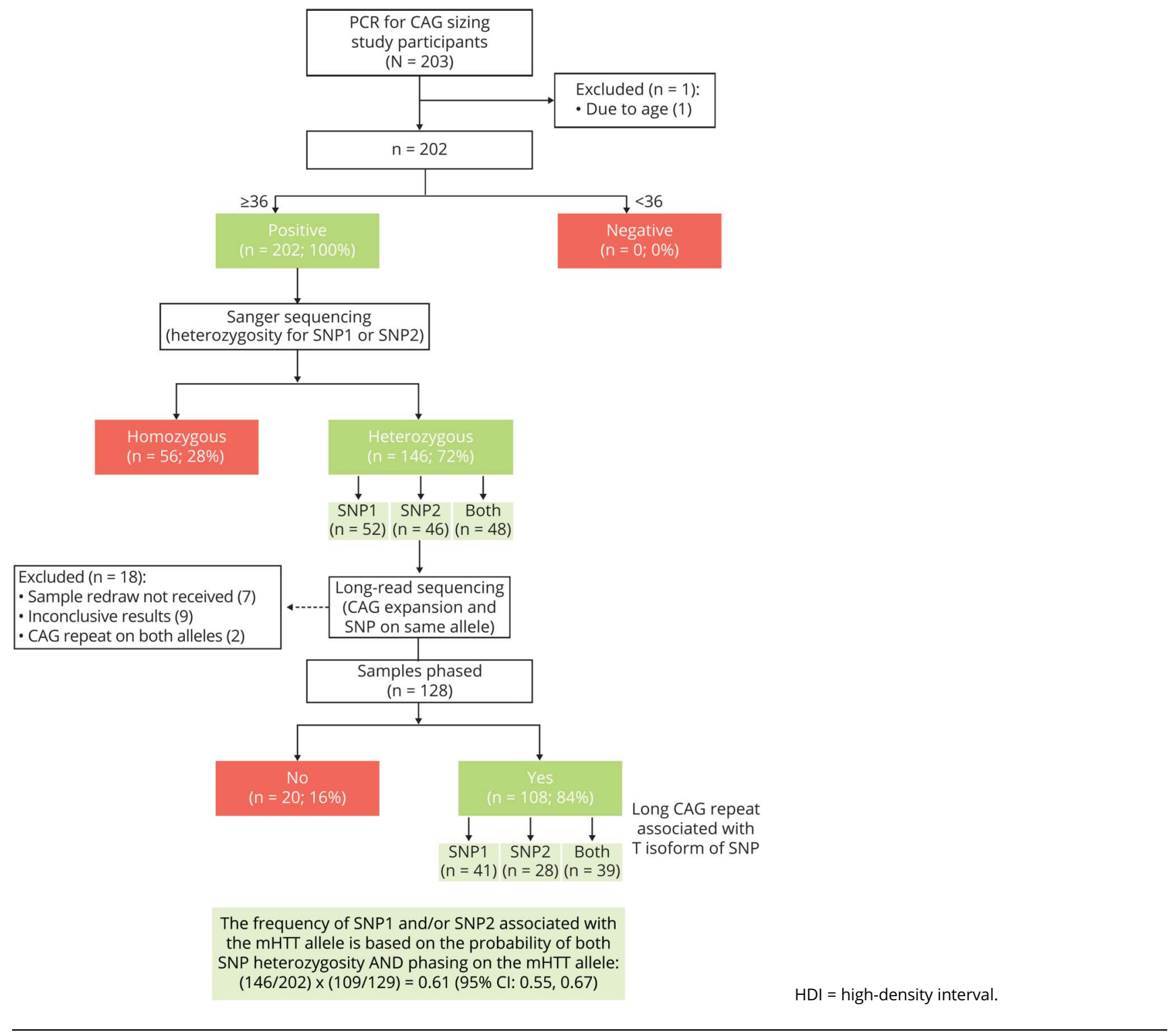

Canadians of European origin $(\mathrm{n}=65)$ and confirmed in a replication group $(n=203) .{ }^{9}$ Of 190 SNPs identified, $23 \%$ were common (minor allele frequency $>0.20$ ). The maximum coverage of a single SNP was 52\%, whereas targeting between 1 and 4 SNPs was theorized to cover $89 \%$ of the HD population.

The ability to prospectively define an individual's specific HTT SNP haplotype permits consideration of personalized allele-selective gene-silencing methods. In the PRECISIONHD trials (NCT03225833, NCT03225846), the presence of SNP1 and/or SNP2 with the CAG expansion is determined using a similar process. Based on these results, participants receive targeted therapy with WVE-120101 or WVE-120102 for SNP1 and SNP2, respectively, aiming to selectively lower $m H T T$ without affecting $w t H T T$. These investigational compounds are stereopure antisense oligonucleotides (ASOs) synthesized by precisely controlling the chirality of the phosphorothioate linkages to enable selective targeting of the SNPs of interest. In general, stereopure ASOs have increased lipophilicity and stability and enhanced RNase $\mathrm{H} 1$ activity than comparable stereorandom ASOs. ${ }^{10}$

This study confirms the feasibility of rapidly detecting SNP1 and/or SNP2 in the HD population in the United States and opens the possibility of selectively targeting mHTT transcript in eligible patients. It is important that the proof of concept of this approach may lead to the identification and targeting of other SNPs in the HD population, allowing others to potentially benefit from allele-selective treatment. 

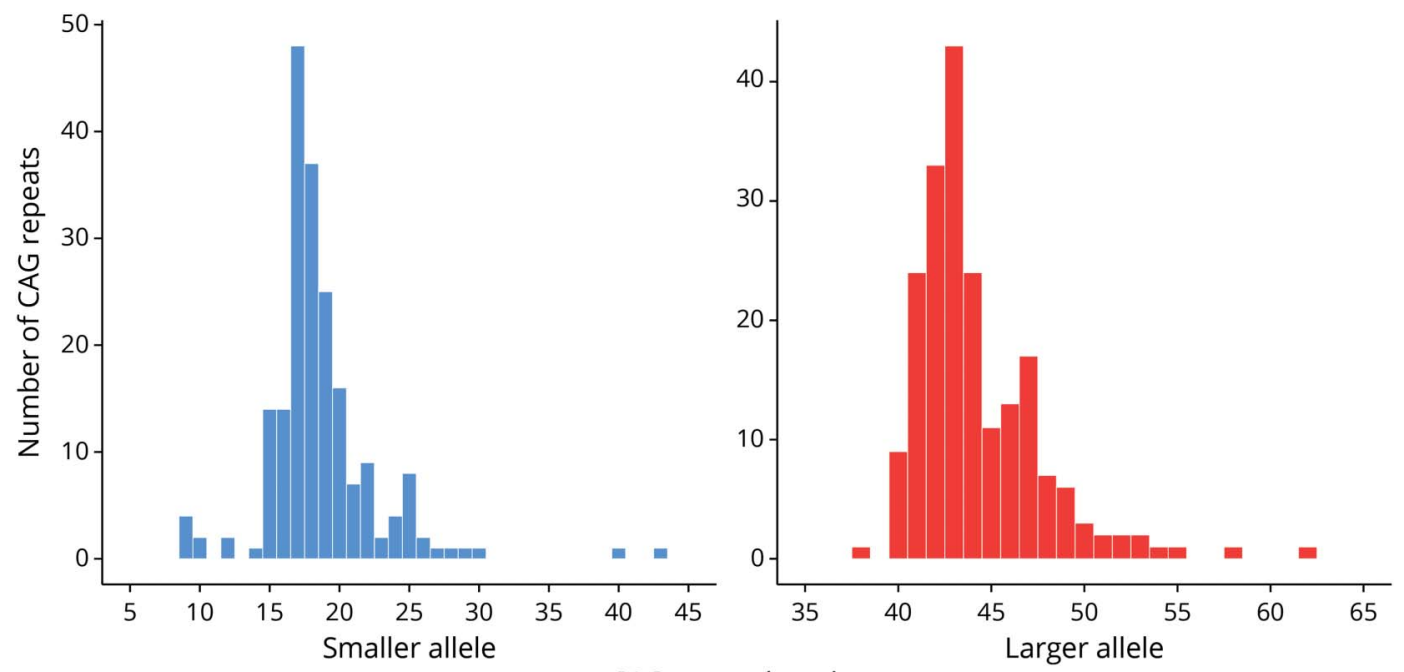

CAG repeat length

The normal allele with 18 CAG repeats and the mutant allele with 43 CAG repeats were shown to be the frequently occurring genotype for $H T T$ in the patients tested. The data did not pass the normal distribution using the Shapiro-Wilk normality test.

\section{Acknowledgment}

The authors thank Shawn Levy, Nripesh Prasad, and Dan Dorset at HudsonAlpha for performing Sanger sequencing and phasing assay, Giulia Malferrari at Biorep for performing CAG testing, and Ramakrishna Boyanapalli from Wave Life Sciences for his input and oversight on the assay and data.

\section{Study funding}

No targeted funding reported.

\section{Disclosure}

The study was sponsored by Wave Life Sciences Ltd., Cambridge, MA. D.O. Claassen has served as a consultant/advisory board member for Lundbeck, Teva Neuroscience, Acadia, AbbVie, and Wave Life Sciences. J. Corey-Bloom has received research support from CHDI, Roche/Genentech, Teva Pharmaceuticals, and Vaccinex Inc.; she is on the speakers bureau for Roche/Genentech and Teva Pharmaceuticals. W.R. Dorsey has received honoraria for speaking at the American Academy of Neurology courses, the American Neurologic Association, and the University of Michigan; received compensation for consulting services from 23andMe, AbbVie, American Well, Biogen, CLINTREX, DeciBio, Denali Therapeutics, GlaxoSmithKline, Grand Rounds, Karger, Lundbeck, MC10, MedAvante, Medical-legal services, Mednick Associates, NINDS, Olson Research Group, Optio, Prilenia, Putnam Associates, Roche, Sanofi, Shire, Sunovion Pharma, Teva, UCB, and Voyager Therapeutics; received grants from Abbvie, Acadia Pharmaceuticals, AMC Health, BioSensics, Burroughs Wellcome Fund, Davis Phinney Foundation, Duke University, Food and Drug Administration, GlaxoSmithKline, Greater Rochester Health Foundation, Huntington Study Group,
Michael J. Fox Foundation, NIH/NINDS, National Science Foundation, Nuredis Pharmaceuticals, Patient-Centered Outcomes Research Institute, Pfizer, Prana Biotechnology, Raptor Pharmaceuticals, Roche, Safra Foundation, Teva Pharmaceuticals, and the University of California Irvine; provides editorial services for Karger Publications; and has ownership interests with Blackfynn (data integration company) and Grand Rounds (second opinion service). M. Edmondson reports no disclosures. S.K. Kostyk has received clinical trial research support from Wave Life Sciences; grants from Huntington's Disease Society of America, CHDI Foundation, Roger A Vaughn Fund/Columbus Medical Foundation, Azevan/NIH/NINDS NeuroNext STAIR trial, Voyager Therapeutics, Vaccinex, Pfizer, and Auspex/Teva; personal fees for travel/consulting from Lundbeck; and honoraria for speaking at Huntington Study Group. M.S. LeDoux has received a grant from Wave Life Sciences. R. Reilmann reports payments to GeorgeHuntington-Institute from Teva, Pfizer, uniQure, Wave Life Sciences, Roche, Ipsen, Vaccinex, Mitoconix, Prilenia, Raptor, Omeros, Prana Biotechnology, Desitin, and AOP Orphan. H.D. Rosas has received grant support from NINDS and is a consultant for Wave Life Sciences. F. Walker has received grants from Vaccinex, Pfizer, and Teva; and consulting fees from AskBio. V. Wheelock has received compensation as a consultant for Roche Pharmaceuticals. N. Svrzikapa, K.A. Longo, J. Goyal, S. Hung, and M.A. Panzara are employees of Wave Life Sciences USA, Inc. Go to Neurology.org/NG for full disclosures.

\section{Publication history}

Received by Neurology: Genetics September 17, 2019. Accepted in final form February 24, 2020. 
Appendix Authors

\begin{tabular}{|c|c|c|c|}
\hline Name & Location & Role & Contribution \\
\hline $\begin{array}{l}\text { Daniel } \\
\text { Claassen, } \\
\text { MD }\end{array}$ & $\begin{array}{l}\text { Vanderbilt } \\
\text { University, } \\
\text { Nashville, TN }\end{array}$ & $\begin{array}{l}\text { Lead and } \\
\text { corresponding } \\
\text { author }\end{array}$ & $\begin{array}{l}\text { Study design; } \\
\text { subject } \\
\text { recruitment/ } \\
\text { acquisition of } \\
\text { data; analyzed } \\
\text { and interpreted } \\
\text { the data; drafted } \\
\text { the manuscript } \\
\text { for intellectual } \\
\text { content }\end{array}$ \\
\hline $\begin{array}{l}\text { Jody Corey- } \\
\text { Bloom, MD }\end{array}$ & $\begin{array}{l}\text { University of } \\
\text { California San } \\
\text { Diego }\end{array}$ & Author & $\begin{array}{l}\text { Subject } \\
\text { recruitment/ } \\
\text { acquisition of } \\
\text { data; analyzed } \\
\text { and interpreted } \\
\text { the data; } \\
\text { revised the } \\
\text { manuscript for } \\
\text { intellectual } \\
\text { content }\end{array}$ \\
\hline $\begin{array}{l}\text { E. Ray } \\
\text { Dorsey, MD }\end{array}$ & $\begin{array}{l}\text { University of } \\
\text { Rochester, NY }\end{array}$ & Author & $\begin{array}{l}\text { Study design; } \\
\text { analyzed and } \\
\text { interpreted } \\
\text { the data; } \\
\text { revised the } \\
\text { manuscript for } \\
\text { intellectual } \\
\text { content }\end{array}$ \\
\hline $\begin{array}{l}\text { Mary } \\
\text { Edmondson, } \\
\text { MD }\end{array}$ & $\begin{array}{l}\text { HD Reach, } \\
\text { Raleigh, NC }\end{array}$ & Author & $\begin{array}{l}\text { Study design; } \\
\text { analyzed and } \\
\text { interpreted } \\
\text { the data; } \\
\text { revised the } \\
\text { manuscript for } \\
\text { intellectual } \\
\text { content }\end{array}$ \\
\hline $\begin{array}{l}\text { Sandra K. } \\
\text { Kostyk, MD, } \\
\text { PhD }\end{array}$ & $\begin{array}{l}\text { Ohio State } \\
\text { University, } \\
\text { Columbus }\end{array}$ & Author & $\begin{array}{l}\text { Subject } \\
\text { recruitment/ } \\
\text { acquisition of } \\
\text { data; analyzed } \\
\text { and interpreted } \\
\text { the data; } \\
\text { revised the } \\
\text { manuscript for } \\
\text { intellectual } \\
\text { content }\end{array}$ \\
\hline $\begin{array}{l}\text { Mark S. } \\
\text { LeDoux, MD, } \\
\text { PhD }\end{array}$ & $\begin{array}{l}\text { University of } \\
\text { Memphis and } \\
\text { Veracity } \\
\text { Neuroscience, } \\
\text { LLC, Memphis, } \\
\text { TN }\end{array}$ & Author & $\begin{array}{l}\text { Study design; } \\
\text { subject } \\
\text { recruitment/ } \\
\text { acquisition of } \\
\text { data; analyzed } \\
\text { and interpreted } \\
\text { the data; } \\
\text { revised the } \\
\text { manuscript } \\
\text { for intellectual } \\
\text { content }\end{array}$ \\
\hline $\begin{array}{l}\text { Ralf } \\
\text { Reilmann, } \\
\text { MD }\end{array}$ & $\begin{array}{l}\text { George- } \\
\text { Huntingon- } \\
\text { Institute and } \\
\text { Dept. of Clinical } \\
\text { Radiology, } \\
\text { University of } \\
\text { Muenster, Hertie } \\
\text { Institute for } \\
\text { Clinical } \\
\text { Brain Research, } \\
\text { University } \\
\text { of Tuebingen, } \\
\text { Germany }\end{array}$ & Author & $\begin{array}{l}\text { Study design; } \\
\text { analyzed and } \\
\text { interpreted } \\
\text { the data; } \\
\text { revised the } \\
\text { manuscript for } \\
\text { intellectual } \\
\text { content }\end{array}$ \\
\hline
\end{tabular}

Appendix (continued)

\begin{tabular}{|c|c|c|c|}
\hline Name & Location & Role & Contribution \\
\hline $\begin{array}{l}\text { H. Diana } \\
\text { Rosas, MD }\end{array}$ & $\begin{array}{l}\text { Harvard Medical } \\
\text { School, } \\
\text { Massachusetts } \\
\text { General Hospital, } \\
\text { Boston }\end{array}$ & Author & $\begin{array}{l}\text { Study design; } \\
\text { subject } \\
\text { recruitment/ } \\
\text { acquisition of } \\
\text { data; analyzed } \\
\text { and interpreted } \\
\text { the data; } \\
\text { revised the } \\
\text { manuscript for } \\
\text { intellectual } \\
\text { content }\end{array}$ \\
\hline $\begin{array}{l}\text { Francis } \\
\text { Walker, MD }\end{array}$ & $\begin{array}{l}\text { Wake Forest } \\
\text { University School } \\
\text { of Medicine, } \\
\text { Winston Salem, } \\
\text { NC }\end{array}$ & Author & $\begin{array}{l}\text { Analyzed and } \\
\text { interpreted } \\
\text { the data and } \\
\text { revised } \\
\text { the manuscript } \\
\text { for intellectual } \\
\text { content }\end{array}$ \\
\hline $\begin{array}{l}\text { Vicki } \\
\text { Wheelock, } \\
\text { MD }\end{array}$ & $\begin{array}{l}\text { University of } \\
\text { California Davis } \\
\text { Health, } \\
\text { Sacramento }\end{array}$ & Author & $\begin{array}{l}\text { Subject } \\
\text { recruitment/ } \\
\text { acquisition of } \\
\text { data; analyzed } \\
\text { and interpreted } \\
\text { the data; } \\
\text { revised the } \\
\text { manuscript for } \\
\text { intellectual } \\
\text { content }\end{array}$ \\
\hline $\begin{array}{l}\text { Nenad } \\
\text { Svrzikapa, } \\
\text { MS }\end{array}$ & $\begin{array}{l}\text { Wave Life } \\
\text { Sciences USA, } \\
\text { Inc., Cambridge, } \\
\text { MA; University of } \\
\text { Oxford, United } \\
\text { Kingdom }\end{array}$ & Author & $\begin{array}{l}\text { Study design; } \\
\text { analyzed and } \\
\text { interpreted } \\
\text { the data; } \\
\text { revised } \\
\text { the manuscript } \\
\text { for intellectual } \\
\text { content }\end{array}$ \\
\hline $\begin{array}{l}\text { Kenneth A. } \\
\text { Longo, PhD }\end{array}$ & $\begin{array}{l}\text { Wave Life } \\
\text { Sciences USA, } \\
\text { Inc., Cambridge, } \\
\text { MA }\end{array}$ & Author & $\begin{array}{l}\text { Study design; } \\
\text { analyzed and } \\
\text { interpreted } \\
\text { the data; } \\
\text { revised the } \\
\text { manuscript } \\
\text { for intellectual } \\
\text { content }\end{array}$ \\
\hline $\begin{array}{l}\text { Jaya Goyal, } \\
\text { PhD }\end{array}$ & $\begin{array}{l}\text { Wave Life } \\
\text { Sciences USA, } \\
\text { Inc., Cambridge, } \\
\text { MA }\end{array}$ & Author & $\begin{array}{l}\text { Study design; } \\
\text { analyzed and } \\
\text { interpreted } \\
\text { the data; revised } \\
\text { the manuscript } \\
\text { for intellectual } \\
\text { content }\end{array}$ \\
\hline $\begin{array}{l}\text { Serena } \\
\text { Hung, MD }\end{array}$ & $\begin{array}{l}\text { Wave Life } \\
\text { Sciences USA, } \\
\text { Inc., Cambridge, } \\
\text { MA }\end{array}$ & Author & $\begin{array}{l}\text { Study design; } \\
\text { subject } \\
\text { recruitment/ } \\
\text { acquisition of } \\
\text { data; analyzed } \\
\text { and interpreted } \\
\text { the data; revised } \\
\text { the manuscript } \\
\text { for intellectual } \\
\text { content }\end{array}$ \\
\hline $\begin{array}{l}\text { Michael A. } \\
\text { Panzara, } \\
\text { MD, MPH }\end{array}$ & $\begin{array}{l}\text { Wave Life } \\
\text { Sciences USA, } \\
\text { Inc., Cambridge, } \\
\text { MA }\end{array}$ & Author & $\begin{array}{l}\text { Study design; } \\
\text { analyzed and } \\
\text { interpreted the } \\
\text { data; revised the } \\
\text { manuscript for } \\
\text { intellectual } \\
\text { content }\end{array}$ \\
\hline
\end{tabular}




\section{References}

1. Kay C, Skotte NH, Southwell AL, Hayden MR. Personalized gene silencing therapeutics for Huntington disease. Clin Genet 2014;86:29-36.

2. Leavitt BR, van Raamsdonk JM, Shehadeh J, et al. Wild-type huntingtin protects neurons from excitotoxicity. J Neurochem 2006;96:1121-1129.

3. Dietrich P, Johnson IM, Alli S, Dragatsis I. Elimination of huntingtin in the adult mouse leads to progressive behavioral deficits, bilateral thalamic calcification, and altered brain iron homeostasis. PLoS Genet 2017;13:e1006846.

4. Gauthier LR, Charrin BC, Borrell-Pages M, et al. Huntingtin controls neurotrophic support and survival of neurons by enhancing BDNF vesicular transport along microtubules. Cell 2004;118:127-138.

5. Pfister EL, Kennington L, Straubhaar J, et al. Five siRNAs targeting three SNPs may provide therapy for three-quarters of Huntington's disease patients. Curr Biol 2009; 19:774-778.
6. van Bilsen PH, Jaspers L, Lombardi MS, Odekerken JC, Burright EN, Kaemmerer WF. Identification and allele-specific silencing of the mutant huntingtin allele in Huntington's disease patient-derived fibroblasts. Hum Gene Ther 2008;19: $710-719$.

7. Huntington Study Group. Unified Hungtington's Disease Rating Scale: reliability and consistency. Mov Disord 1996;11:136-142.

8. Lombardi MS, Jaspers L, Spronkmans C, et al. A majority of Huntington's disease patients may be treatable by individualized allele-specific RNA interference. Exp Neurol 2009;217:312-319.

9. Warby SC, Montpetit A, Hayden AR, et al. CAG expansion in the Huntington disease gene is associated with a specific and targetable predisposing haplogroup. Am J Hum Genet 2009;84:351-366.

10. Iwamoto N, Butler DC, Nenad S, et al. Control of phosphorothioate stereochemistry substantially increases the efficacy of antisense oligonucleotides. Nat Biotechnol 2017; $35: 845-851$. 


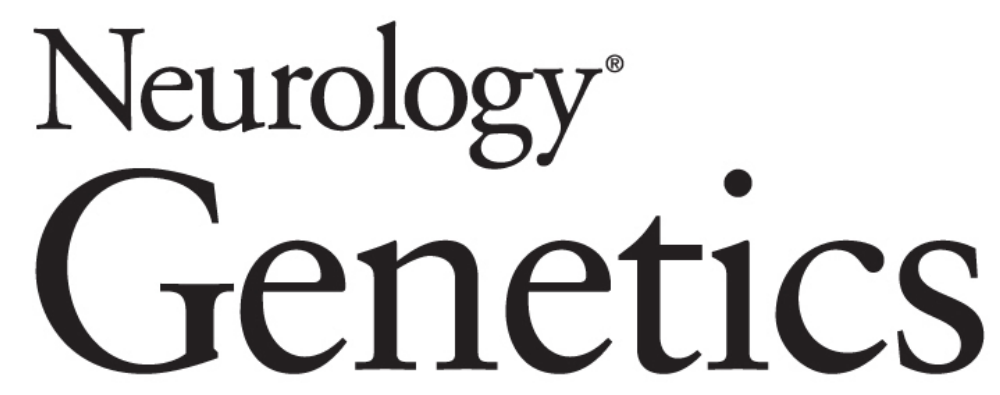

\section{Genotyping single nucleotide polymorphisms for allele-selective therapy in Huntington disease}

Daniel O. Claassen, Jody Corey-Bloom, E. Ray Dorsey, et al.

Neurol Genet 2020;6;

DOI 10.1212/NXG.0000000000000430

This information is current as of May 14, 2020

\section{Updated Information \& Services}

References

Citations

Subspecialty Collections

Permissions \& Licensing

Reprints including high resolution figures, can be found at: http://ng.neurology.org/content/6/3/e430.full.html

This article cites 10 articles, 0 of which you can access for free at: http://ng.neurology.org/content/6/3/e430.full.html\#\#ref-list-1

This article has been cited by 1 HighWire-hosted articles: http://ng.neurology.org/content/6/3/e430.full.html\#\#otherarticles

This article, along with others on similar topics, appears in the following collection(s):

Gene expression studies

http://ng.neurology.org//cgi/collection/gene_expression_studies

Huntington's disease

http://ng.neurology.org//cgi/collection/huntingtons_disease

Information about reproducing this article in parts (figures,tables) or in its entirety can be found online at:

http://ng.neurology.org/misc/about.xhtml\#permissions

Information about ordering reprints can be found online: http://ng.neurology.org/misc/addir.xhtml\#reprintsus

Neurol Genet is an official journal of the American Academy of Neurology. Published since April 2015, it is an open-access, online-only, continuous publication journal. Copyright Copyright $\odot 2020$ The Author(s). Published by Wolters Kluwer Health, Inc. on behalf of the American Academy of Neurology.. All rights reserved. Online ISSN: 2376-7839.

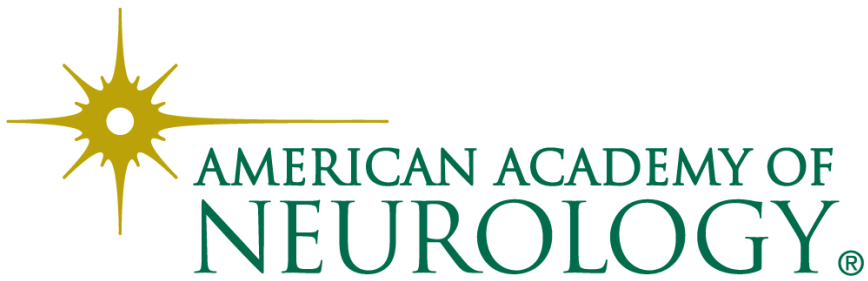

